\title{
Potential role of sacred grove of Lumbini in biodiversity conservation in Nepal
}

\begin{abstract}
Khem Raj Bhattarai ${ }^{1}$ and Sushim R. Baral ${ }^{2}$
This study was conducted in the sacred grove of Lumbini to elucidate its potential role in biodiversity conservation in Nepal. Lumbini Development Trust enumerated tree species of the grove. We have assessed taxonomic validity by identifying the species. A total of 65 tree species, 39 are indigenous to Nepal, were found in the grove. Most of the species were tropical/subtropical elements that are found to be distributed in Nepal from 100 to $2400 \mathrm{~m}$ asl. Among total indigenous trees, $64 \%$ trees have their distribution in the whole Nepal, whereas $19 \%, 14 \%$ and $3 \%$ are limited to central, eastern, and both central and western part of Nepal respectively. The indigenous species found in the grove accounts for $11 \%$ of total tree diversity of Nepal. Of these tree species, five are of threatened, vulnerable and endangered categories. The forest formation of the grove conforms to Dalbergia sisoo-Acacia catechu type's forest of Nepal. However, majority of the trees in the grove were produced by plantation so it has contributed to ex-situ conservation of trees, and hence this reflects the importance of sacred grove.
\end{abstract}

Key words: conservation, distribution, indigenous trees, Lumbini, Sacred grove, sacred plants, tree species.

$\mathbf{T}$ he sacred groves are small patch of forests conserved through man's religious beliefs since human civilization that comprise valuable genetic resources (Basu, 2000; Jamir and Pandey, 2003). They have become refuges for plants, birds, mammals, and other forest dwelling animals (Dash, 2005), and local community depends upon them for various products used in everyday life (Wadley and Colfer, 2004). The sacred groves are found throughout the world in different temporal and spatial scales, and have contributed significantly for conservation of rare and endangered species (Mgumia and Oba, 2003). In the earlier centuries, conservation programs were based on religion and spiritual belief as reflected from the practices like i) people used to plant trees as an offering to god, ii) forests were used to preserve as religious sites, iii) new species used to introduce from pilgrimage tour and preserved them in sacred grove. Some of the ruminants of forests were also preserved as sacred groves due to its historical significance and spiritual value (Dash, 2005).

Although the sacred groves are economically and religiously important, these are getting pressure from local community through over harvesting for fuel wood, timber, fodder and grazing their cattle. These human pressures may possibly lead to decline in the species diversity and changing in floristic composition. Inventories of species preserved in the particular sacred grove may provide information about dynamics of plant communities, rationale of preservation in the past, history and socio-cultural values linked with particular species and societies (Bhagwat and Rutte, 2006).

Some of the sacred groves have emerged by planting species with medicinal, religious and aesthetic value (Dash, 2005). These sorts of activities are still in practices and have existed in Nepal since the historic periods of Budha, Lichbibi, Mallas and Rana. Therefore, several sacred groves are expected to be found in Nepal ranging from tropical to alpine climatic zone, but their inventories and potential role in the conservation of biodiversity have not been documented so far.

Nepal is richer in its ethnic diversity so there are diverse human societies with different social customs; myths and beliefs that are interconnected for the protection and conservation of fauna and flora. Some of the sacred groves have been used as shrines and for spiritual worships (Wadley and Colfer, 2004). Thus,

\footnotetext{
${ }_{1}$ Vegetation Ecologist, National Herbarium and Plant Laboratories, Godawari, Lalitpur

2 Senior Scientific Officer, National Herbarium and Plant Laboratories, Godawari, Lalitpur, GPO Box 3722, Katmandu, Nepal.

Corresponding author: Dr Khem Raj Bhattarai, Email: bhattaraikhemraj@gmail.com, Tel: 9779851085389
} 
conservation of plant species by establishing sacred groves was one of the most widespread practices in the past, which helped to conserve cultural landscapes as well (e.g. Odera, 1997; Posey, 1999). The groves occur in different forms such as remnants of old forests, burial grounds, and sites of ancestral worship (Githitho, 1998; Mgumia and Oba, 2003). However, the sacred groves and their role for conservation of rare and endangered species have been overlooked.

Lumbini has been considered one of the most sacred places on earth amongst Hindus and Budhists. Because of birth place of Lord Budha and valuable historical importance, it has been enlisted by UNESCO as a world heritage site. The birth of Budha has connection with gardens, flowers and trees (see Kausalyayana, 1985). During $7^{\text {th }}$ and $6^{\text {th }}$ centuries BC, Lumbini was a beautiful garden maintained by the Sakya dynasty of Kapilavastu and the Koliyas dynasty of Ramagrama (Bidari 2004). In the Budhist literature, Lumbini is described as sacred grove with blooming sal trees and varieties of beautiful flowers (see Kausalyayana, 1985). Thus, introduction of sacred species in the grove of Lumbini might be a regular practice after birth of Budha.

With the establishment of Lumbini Development Trust in 1985, the area of the grove was extended and planted with hundreds of seedlings of trees belonging to various indigenous and exotic species. Among them, some were rare and endangered (see Shrestha and Joshi, 1996). Inventory of species, evaluation of distribution patterns, floristic composition and adaptation of species in the sacred grove may provide key information useful to promote conservation of rare and endangered species. This study, therefore, intends to: (1) make an inventory of tree species growing in sacred grove of Lumbini, evaluate their regional distribution patterns and floristic composition, (2) classify the trees species of grove according to their use (timber, ornament, medicine and religious purpose), (3) assess the particular forest types formation from existing tree population, and (4) discuss the implication of sacred grove for conservation in general.

\section{Materials and methods}

\section{Study site}

This study was conducted in the sacred grove of Lumbini in Kapilvastu district, close to the Indian boarder (Fig. 1). It is situated at $180 \mathrm{~m}$ above sea level between $27^{\circ} 28^{\prime} \mathrm{N}$

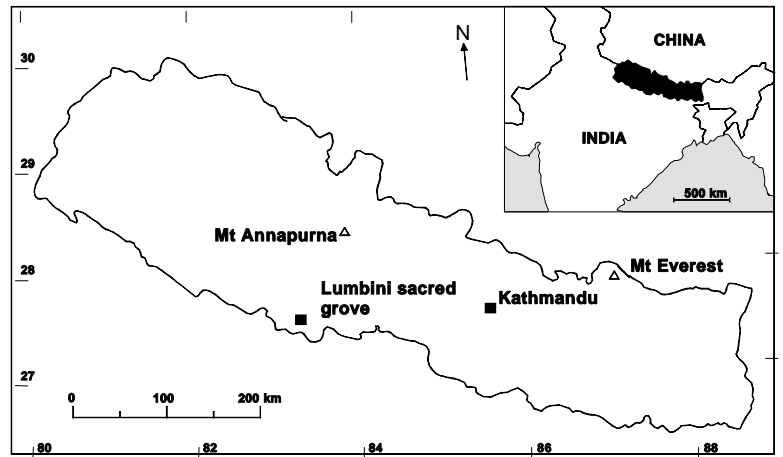

Fig. 1 Location of study area

latitude and $83^{\circ} 430^{\prime} \mathrm{E}$ longitude. It has a monsoon climate similar to that of Indian plateau. The most of the rainfall occurs during summer (from June to September) whereas the winter is relatively dry. The Lumbini belongs to tropical vegetation zone of Nepal. Major dominant forest forming species are: Shorea robusta, Terminalia spp., Lagestroemia parviflora, and Dalbergia sisoo.

\section{Survey, data collection and analysis}

Fieldwork was carried out in June 2007. In order to get information about master plan for conservation and development of Lumbini, a preliminary discussion was done with project manager of Lumbini Development Trust. Vegetation data: botanical species, number of trees, and number of planted seedlings were collected from Lumbini Development Trust which conducted tree census in 2000. To verify this census data, each and every parts of the grove was observed. Some of the species could not be confirmed for the taxonomic identity in the field, so that sample was collected and identified by comparing with voucher specimens (herbaria) preserved in the National Herbarium and Plant Laboratories at Godawari, Lalitpur. In order to obtain information of plant species, their use, religious value, mythological linkage to Buddha, and purpose of introduction of species in the grove; an informal interview and focus group discussion was also conducted with local residents, staff of Lumbini Development Trust and monks of monasteries.

The distribution range and conservation status of the species were based on published literature (e.g. Shrestha and Joshi, 1996; Press et al., 2000; DPR, 2001). In order to find the elevational range of tree species in the natural habitats, the range was interpolated (see Bhattarai and Vetaas, 2006).

Since Nepal Himalayas is divided into three phytogeographical regions: the east, central and west 
(Banerii, 1963), tree species found in the sacred grove of Lumbini were also checked for their longitudinal distribution along these phytogeographical regions. The species found in the grove were categorized according to the red data book prepared by International Union for Conservation of Nature and Natural Resources (IUCN) as endangered, vulnerable, rare, commercially threatened and uncertain species (Shrestha and Joshi, 1996). Scatter plot and descriptive statistics were used to summarize the data.

\section{Results}

\section{Species composition and distribution}

A total of 65 species of tree (angiosperms and gymnosperms) including nine unidentified were found in the sacred grove of Lumbini. These species totaled to 191,448 tree stands. Most of the species were found to be tropical/subtropical element. Among the indigenous trees, majority of them were produced by plantation in different periods of time. The regional distribution pattern of these species along the Himalayan elevation gradient is presented in Fig. 2.

Of the 65 species, 39 are indigenous and 17 are exotic (Table 1 and 2) to Nepal. Regional distribution of these indigenous species was found ranging from 100$2400 \mathrm{~m}$ along the elevation gradient of the Himalayas. Some of the exotic trees could not be identified. Dalbergia sisoo was found to be most dominant tree species that accounted for $85 \%$ of total tree stands, which was followed by Callistemon citrinus and Albizia lebbek that accounted for $2.8 \%$ and $1.98 \%$ of total number of tree stands respectively. Among the indigenous trees, five species fall under the categories of vulnerable, endangered and threatened (Shrestha and Joshi 1996; Kurmi and Bhatta 2003, see Table 1).

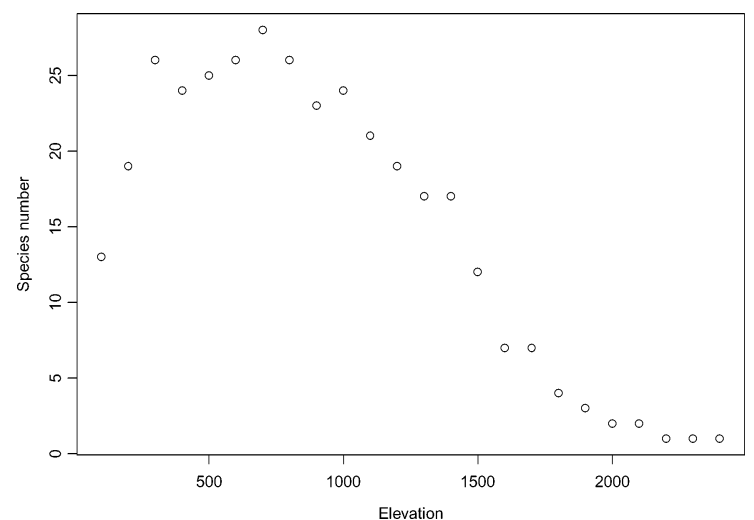

Fig. 2 Regional distribution pattern of indigenous tree species of Lumbini sacred grove along elevation gradient in the Himalayas
Among the indigenous tree species of the grove, 22 were found to be distributed in Nepal Himalayas (WCE), five were found limited only in the centre Nepal (C), and seven species were found both in the centre and east (CE) Nepal (Fig. 3). However, Pterocarpus marsupium was only species reported its natural distribution in the west (W) Nepal (Kurmi and Bhatta 2003), and it was found in the sacred grove as well. The tree species of the grove were found to have medicinal, timber, fodder, religious, and ornamental values. Significant number of tree species found in the grove did not found in the natural habitats. These species were found introduced in the grove. However, purpose of introduction of six tree species could not be ascertained (Table 2).

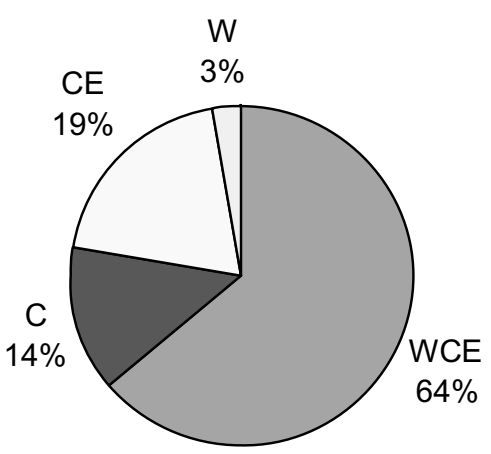

Fig. 3 Proportional phytogeographical distribution of tree species in Nepal

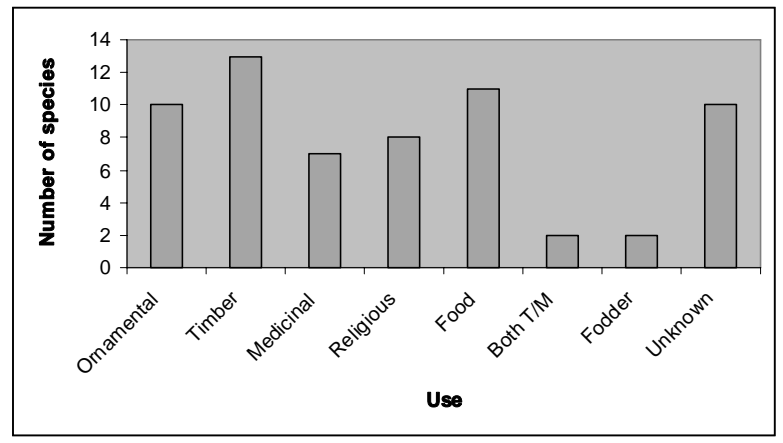

Fig. 4 Proportion of different tree species and their use, $\mathbf{T}=$ Timber, $\mathbf{M}=$ Medicinal 
Table 1: Indigenous trees of Lumbini sacred grove and their distribution pattern in Nepal Himalayas

\begin{tabular}{|c|c|c|c|}
\hline Tree species & $\begin{array}{c}\text { Altitudinal } \\
\text { distribution } \mathrm{m} \text { asl }\end{array}$ & $\begin{array}{c}\text { Biogeographical } \\
\text { distribution }\end{array}$ & Conservation status \\
\hline Acacia catechu & $200-1400$ & WCE & $\mathrm{CT}$ \\
\hline Accacia nilotica & 1500 & C & $\mathrm{N}$ \\
\hline Adina cordifolia & $150-800$ & WCE & $\mathrm{N}$ \\
\hline Aegle marmelos & $300-1100$ & WCE & $\mathrm{N}$ \\
\hline Albizia lebbek & $250-800$ & WCE & $\mathrm{N}$ \\
\hline Anthocephalus chinensis & $290-800$ & $\mathrm{CE}$ & $\mathrm{N}$ \\
\hline Artocarpus beterophyllus & $100-800$ & $\mathrm{C}$ & $\mathrm{N}$ \\
\hline Artocarpus lakocha & $700-1400$ & $\mathrm{C}$ & $\mathrm{N}$ \\
\hline Azadirachta indica & $300-1700$ & $\mathrm{CE}$ & $\mathrm{N}$ \\
\hline Bambusa sp & $400-1200$ & WCE & $\mathrm{N}$ \\
\hline Baubania variegata & $150-1900$ & WCE & $\mathrm{N}$ \\
\hline Bombax ceiba & $200-900$ & $\mathrm{CE}$ & $\mathrm{E}$ \\
\hline Butea monosperma & $150-1200$ & WCE & $\mathrm{E}$ \\
\hline Cassia fistula & $150-1400$ & WCE & $\mathrm{N}$ \\
\hline Cinnamomum camphora & $1300-1500$ & C & $\mathrm{N}$ \\
\hline Dalbergia latifolia & $300-1000$ & WCE & $\mathrm{E}$ \\
\hline Dalbergia sisoo & $200-1400$ & WCE & $\mathrm{N}$ \\
\hline Delonix regia & $200-1100$ & $\mathrm{E}$ & $\mathrm{N}$ \\
\hline Elaeocarpus sphaericus & $700-1700$ & $\mathrm{CE}$ & $\mathrm{V}$ \\
\hline Eugenia formosa & 300 & $\mathrm{E}$ & $\mathrm{N}$ \\
\hline Ficus benghalensis & $500-1200$ & WCE & $\mathrm{N}$ \\
\hline Ficus racemosa & 300 & WC & $\mathrm{N}$ \\
\hline Ficus religiosa & $150-1500$ & WCE & $\mathrm{N}$ \\
\hline Lagestromia indica & $1000-1500$ & WCE & $\mathrm{N}$ \\
\hline Madbuca latifolia & $300-1200$ & C & $\mathrm{N}$ \\
\hline Magnifera indica & $100-1200$ & WCE & $\mathrm{N}$ \\
\hline Mitragyna parviflora & $150-200$ & WCE & $\mathrm{N}$ \\
\hline Moringa oleifera & $150-1100$ & $\mathrm{CE}$ & Un \\
\hline Morus macroura & $1200-1700$ & $\mathrm{E}$ & $\mathrm{N}$ \\
\hline Phyllanthus emblica & $150-1400$ & WCE & $\mathrm{N}$ \\
\hline Pinus roxburghii & $1100-2100$ & WCE & $\mathrm{N}$ \\
\hline Psidium guajava & $200-1200$ & WCE & $\mathrm{N}$ \\
\hline Pterrocarpus marsupium & 100 & W & En \\
\hline Saurauia napaulensis & $750-2100$ & WCE & $\mathrm{N}$ \\
\hline Sesbania orientale & $600-2400$ & WCE & $\mathrm{N}$ \\
\hline Shorea robusta & $150-1500$ & WCE & $\mathrm{N}$ \\
\hline Syzygium jambos & $600-1400$ & $\mathrm{CE}$ & $\mathrm{N}$ \\
\hline Tamarindus indica & $200-400$ & $\mathrm{CE}$ & $\mathrm{N}$ \\
\hline Trewia nudiflora & $150-1800$ & WCE & $\mathrm{N}$ \\
\hline
\end{tabular}

WCE, $\mathrm{W}=$ West, $\mathrm{C}=$ Centre, $\mathrm{E}=$ East, $\mathrm{N}=$ Normal, $\mathrm{En}=$ Endangered, $\mathrm{CT}=$ Commercially threatened, $\mathrm{V}=$ Vulnerable, $\mathrm{Un}_{\mathrm{n}}=$ Status unknown

\section{Discussion}

\section{Tree species richness and forest formation}

Tree species found at sacred grove of Lumbini accounted for ca. $11 \%$ of total tree species of Nepal. These species were distributed along the elevation gradient of the Himalayas from $100 \mathrm{~m}$ to over 2000 $\mathrm{m}$. There are total 614 tree species found in Nepal, which are distributed from 100-4400 m (Bhattarai and Vetaas, 2006). Although, grove was located at $180 \mathrm{~m}$ above sea level the tree species were distributed below and above this range (Fig. 2.). This indicated that the species have wider distribution range. Relatively, species having wider range of distribution are considered as more adapted in the natural habitats (Subedi et al., 2007). 
The dominant tree species in the grove were Dalbergia sisoo, Albiria lebbek, Callistemon citrinus, and Acacia catechu. Except Callistemon citrinus others were indigenous to tropical parts of Nepal. Majority of the trees of the grove were produced by plantation, so that the newly emerged forest patch could be assumed as tropical type with different species composition than the natural forest. According to forest classification based on species composition, the forest formation of the grove falls under the category of Dalbergia sisoo-Acacia catechu types of Nepal (Stainton, 1972), which is common in new alluvial deposit along the streams and rivers of terai and $d u n$ valleys.

Of all the tree species in the grove, Dalbergia sisoo accounted for $85 \%$ whereas rest of species accounted for only $15 \%$. The $15 \%$ of various other species might be insignificant in number in order to maintain the integrity of ecosystem. The majority of species accounted for less than $1 \%$ among the total stands, showed that this was almost monoculture plantation of Dalbergia sisoo. There is a long-standing debate over whether to use mono- or polyculture when establishing plantations. Hartley (2002) reviewed the literature and found that polyculture was found to be beneficial against monoculture in many parts of the world. These benefits include: (1) more efficient nutrient use (2) site quality and yields are conserved over time (3) reduced risk of catastrophic damage from storms, insects, or disease outbreak (4) some species provide nurse effect to neighboring species and protect against shade, frost, etc. (5) enhance higher ecological integrity due to higher species diversity. Research has shown that polyculture species are more resistant and can use nutrients more efficiently than monoculture do because of differences among species in rooting patterns, mycorrhizal associations (Perry et al.,1992), phenology (Keenan et al., 1995), nutrient demands
(Kelty, 1992), and soil mineralization rates (Matthews, 1989). Adhikari et al. (2006) have found that the major die back disease in monoculture plantation of Dalbergia sisoo in Lumbini was mainly caused by fungi (Ganodorma lucidum and Fussarium solani).

Table 2. Exotic tree species and their purpose of their introduction in the sacred grove

\begin{tabular}{ll}
\hline \multicolumn{1}{c}{ Species } & Purpose of introduction \\
\hline Callistemon citrinus & Ornamental \\
Tectona grandis & Timber \\
Eucalyptus camaldulensis & Medicinal \\
Terminalia arjuna & Medicinal/religious \\
Leucaena leucochephala & Fodder \\
Polyalthea longifolia & Religious/ornamental \\
Acacia mollissima & $?$ \\
Thuja compacta & Ornamental \\
Ficus sp. & Fodder \\
Oreodoxa regia & Ornamental \\
Mimusops elengi & $?$ \\
Ficus idostics & $?$ \\
Polyalthea barmige & Religious/ornamental \\
Pitheceolobium sp & $?$ \\
Populus sp & Ornamental \\
Annona squamosa & Food \\
Jacaranda mimosifolia & Ornamental \\
\hline
\end{tabular}

According to phytogeographical division of Nepal, the sacred grove of Lumbini is located at the boarder between central and western Nepal. Three species Delonix regia, Eugenia formosa and Morus macoura which are found only in east Nepal were also found in the grove. Similarly, there were five species limited to central Nepal and only one species of west were found in the sacred grove. These species were not found in the natural forests around the sacred grove (see Stainton, 1972). Such evidence may indicate that beside natural regeneration, tree species might have introduced from other parts of Nepal. Thus, sacred grove of Lumbini has played an important role for ex-situ conservation of tree diversity in Nepal.

Table 3: Sacred species of the grove and their symbolization as deities

\begin{tabular}{lll}
\hline \multicolumn{1}{c}{ Botanical species } & \multicolumn{1}{c}{ Local name } & Associated god/goddess \\
\hline Anthocephalus chinensis & Kadam & God Krishna \\
Azadiarachta indica & Neem & Goddes Sita \\
Baubinia variegata & Koiralo & God Bishnu \\
Butea monosperma & Palsh & God Shiva \\
Eragrostis cynosuroides* & Kush & God Vishnu \\
Ficus bengalensis & Bar & God Burhma \\
Ficus religiosa & Peepal & God Bishnu \\
Hibiscus rosasinensis** & Japapuspi & Goddes Durga \\
Saraca indica & Ashok & God Kamadev \\
\hline ** Shrub and * grass & &
\end{tabular}




\section{Sacred grove and conservation in Nepal}

Lord Budha was born under the tree of saal (Shorea robusta) which is considered sacred as a mother goddess (Bidari, 2004). However, some people are in the opinion that the tree was Ashoka (Saraca indica) not a Shorea robusta. According to Budhist literature, Maya Devi (mother of Budha) wished to be at the base of a tree and gazing upon the garden-grove in Lumbini at the time of delivery. After birth of Budha, people started to worship the tree and the worshipping become very popular and common among the people of that period. Lumbini Dvelopment Trust has planted various religious trees in the grove and continued the religious tradition. At present there were ca. $9 \%$ of trees species in the grove were considered as religious (Fig. 4). Various Hindu deities and their forms have been symbolically associated with these species (Table 3). Majpuria (1999) have reported 56 sacred plant species from Nepal. The most worshipped trees are flower bearing with medicinal values.

Beside tree, there is a sacred grass (Eragrostis cynosuroides) and a sacred shrub (Hibiscus rosasinensis) species in the grove. These species have been preserved because of their associated religious and spiritual beliefs. Hence, these plant species are worshipped. Felling and destruction upon religious species is considered against the sprit of religion. Such religious beliefs have played important role for conservation of these trees in the grove from centuries. Now time has come to check what species have been preserved in the grove of Lumbini.

Although Dalbergia sisoo having no religious and ornamental value was still dominant tree in the grove. The plantation, which was done by Lumbini Development Trust in the earlier days, might have focused to increase the greenery rather than beautifying the grove. Some species, Bombax ceiba, Butea monosperma, Dalbergia latifolia are endangered tree species are conserved in the grove. Beside indigenous trees, 17 exotic tree species were introduced in the grove (Table 2). Some of the introduced species were highly valuable due to their medicinal properties (e.g. Teminalia arjuna).

Recently, Lumbini Development Trust is constructing a sacred pond around the periphery of birthplace of Budha, which is going be a potential habitat for several species of birds and aquatic life forms. Aquatic plant like Nelumbium speciosum has been introduced in the aquatic habitats of the grove. This shows that grove may provide the habitat for endangered, rare and sacred species of plants. Thus, potential role of sacred grove in biodiversity conservation of Nepal would be realized and conservation programs would be formulated for the better management and conservation of grove.

\section{Acknowledgements}

We thank Mr Subhash Khatri for providing information and guiding trip to Lumbini. The Mr Krishna Dhakal, Ram Bahadur Chhetri, Harun Mohamod Khan, and Kamlesh Burma are acknowledged for their cooperation during fieldwork. Mr. P.P. Kurmi has helped to confirm three tree species. Dr Thakur Upadhaya has corrected English and provided constructive comments. National Herbarium and Plant Laboratories, Godawari, Nepal supported fieldwork.

\section{References}

Adhikari, M.K.; Manandhar, V. and Kurmi, P.P. 2006. Die back of Dalbergia sisoo Roxb. Ex. Dc in western Terai belt of Nepal. Plant Resources, Bull.Dep.Pl. Res. 27:30-38.

Banerji, M.L. 1963. Outline of Nepal phytogeography. Vegetatio 5-6:88-296.

Basu, R. 2000. Studies on sacred groves and taboos in Purulia District of West Bengal. Indian Forester 121:1309-1318.

Bhagwat, S. and Rutte C. 2006. Sacred groves: potential for biodiversity management. Frontiers in Ecology and the Environment 4:519-524.

Bhattarai, K.R. and Vetaas, O.R. 2006. Can Rapoport's elevation rule explains the tree species richness along the Himalayan elevation gradient, Nepal? Diversity and Distributions 12:373-378.

Bidari, B. 2004. Lumbini a haven of sacred refuge. Hill Side Press (P) Ltd, Katmandu.

Chalise, M.K. (1998) Wildlife of Nepal. Nepal Natural History Society, Katmandu, pp. 1-56.

Dash, S.S. 2005. Kabi sacred grove of North Sikkim. Current Science 89: 427-428.

DPR, Deparment of Plant Resources 2001. Flowering plants of Nepal. Department of Plant Resources, Katmandu, Nepal. 
Hartley, M.J. 2006. Rationale and methods for conserving biodiversity in plantation forests. Forest Ecology and Management 155:81-95.

Jamir, S.A. and Pandey, H.N. 2003. Vascular plant diversity in the sacred groves of Jaintia Hills in northeast India. Biodiversity and Conservation 12:1497-1510.

Kausalyayana, Ven. A. 1985. Jataka (First part). Hindi Sabita Sammlena, Allahabad, India.

Keenan, R., Lamb, D. and Sexton, G. 1995. Experience with mixed species rainforest plantations in north Queensland. Common For. Rev., 74:315-321.

Kelty, M.J. 1992. Comparative productivity of monocultures and mixed-species stands. In: The Ecology and Silviture of Mixed-species Forests, ed. M.J. Kelty, pp. 125-141. Kulwer Academic Publishers, The Netherlands.

Kurmi, P.P. and Bhatta, G.D. 2003. A survey report on Pterocarpus marsupium Roxb. From western, Nepal. Plant Resources. Bulletion of Department of Plant Resources no. 22,89-96.

Matthews, J.D. 1989. Sivicultural Systems. Clarendon Press, Oxford, 284 pp.

Wadley, R. L. and Colfer, C.J.P. 2004. Sacred forests, hunting, and conservation in west Kalimantan, Indonesia. Human Ecology 32:313-338.

Mgumia, F.H. and Oba, G. 2003. Potential role of sacred groves in biodiversity conservation in Tanzania. Environmetal Conservation,30:259265.
Odera, J.A. 1997. Traditional beliefs, sacred groves and home garden techonologies. Adapting old practices for conservation of medicinal plants. In: Conservation and Utilization of medicinal plants and wild relatives of food crops, ed. A.M. kenyua, W.M. Kofi-Teskpo and L.B. Dangana, pp. 19-28. Nairobi, Kenya.

Perry, D.A., Bell T. and Amaranthus, M.P. 1992. Mycorrhizal fungi in mixed species forests and other tales of positive feedback, redundancy and stability. In: Cannell, M.G.R. Malcolm; D.C., Robertson, P.A. (Eds.), The Ecology of mixedspecies stands of Trees. Blackwell Scientific Publications, Oxford, pp.151-179.

Posey, D.A. 1999. Cultural and spiritual values of biodiversity. A complementary contribution to the Global Biodiveversity Assessment. Nairobii, Kenya: United Nations Environment Programme.

Press, J.A.,Srestha, K.K. and Sutton, D.D. 2000. Annotated checklist of the flowering plants Nepal. The Natural History Museum, London.

Shrestha, T. and Joshi, R.M. 1996. Rare, endemic and endangered plants of Nepal. WWF Nepal Program, Katmandu, Nepal.

Stanton, J.D.A. 1972. Forest of Nepal. John Murray Publishers, Ltd.UK.

Subedi, S.C. , Bhattarai, K.R. and Chaudhary, R.P. 2007. Distribution pattern of Manang's species along the whole Himlayan elevation gradient and their fate against global warming. Himalayan Journal of Science (accepted). 